\title{
Healthcare Disparities Correlated with In-Hospital Mortality in COVID-19 Patients
}

\author{
Rachel Harvey' \\ Maryan Hermez' \\ Luke Schanz ${ }^{2}$ \\ Patrick Karabon ${ }^{3}$ \\ Tracy Wunderlich-Barillas ${ }^{3}$ \\ Alexandra Halalau (iD) ${ }^{1,2}$ \\ 'Oakland University William Beaumont \\ School of Medicine, Rochester, MI, USA; \\ ${ }^{2}$ Internal Medicine Department, \\ Beaumont Health, Royal Oak, MI, USA; \\ ${ }^{3}$ Office of Research, Oakland University \\ William Beaumont School of Medicine, \\ Rochester, MI, USA
}

\begin{abstract}
Introduction: Increasing age, male gender, African American race, and medical comorbidities have been reported as risk factors for COVID-19 mortality. We aimed to identify healthcare disparities associated with increased mortality in COVID-19 patients.

Methods: We performed an observational study of all hospitalized patients with SARSCoV2 infection from within the largest multicenter healthcare system in Southeast Michigan, from February to December, 2020.

Results: From 11,304 hospitalized patients, 1295 died, representing an in-hospital mortality rate of $11.5 \%$. The mean age of hospitalized patients was 63.77 years-old, with $49.96 \%$ being males. Older age $(\mathrm{AOR}=1.05, \mathrm{p}<0.0001)$, male gender $(\mathrm{AOR}=1.43, \mathrm{p}<0.0001)$, divorced status $(A O R=1.25, p=0.0256)$, disabled status $(A O R=1.42, p=0.0091)$, and homemakers $(\mathrm{AOR}=1.96, \mathrm{p}=0.0216)$ were significantly associated with in-hospital mortality.
\end{abstract}

Conclusion: Older age, male gender, divorced and disabled status and homemakers were significantly associated with in-hospital mortality if they developed COVID-19. Further research should aim to identify the underlying factors driving these disparities in COVID19 in-hospital mortality.

Keywords: disparities, COVID-19, mortality, race, disability

\section{Introduction}

The COVID-19 pandemic has overwhelmed health-care systems and led to significant morbidity and mortality. Four factors: older age, male gender, medical comorbidities, and African American race have been associated with higher risk of infection and mortality from COVID-19. ${ }^{1,2}$ Furthermore, health-care disparities, including increased rates of comorbidities are seen disproportionately in marginalized populations including minorities and those with lower socioeconomic status. ${ }^{3}$ While prior studies have shown an increased risk of COVID-19 infection in groups affected by health-care disparities, our study aims to identify if there is a similar increased risk in these groups that is associated with mortality among a large cohort of COVID-19 patients in Michigan.

\section{Methods}

We performed an observational study of hospitalized patients with SARSCoV2 infection diagnosed by RT-PCR nasopharyngeal swab from within the largest healthcare system in Southeast Michigan (8 hospitals), from February 25, 2020 through December 31, 2020. All patients admitted to
Correspondence: Alexandra Halalau Beaumont Health, 360I W I 3 Mile Road, Royal Oak, MI, 48073, USA

Email alexandra.halalau@beaumont.edu 
a Beaumont hospital were included, with the exception of patients missing demographic data and patients who were not permanent Michigan residents. Zip-code-level data from the United States Census Bureau (USCB) such as rate of unemployment, use of public transportation, and percentage of food stamp usage were used as proxies for economic and employment status as this individual-level data was not available from the electronic health record (EHR). The zip-code-level data was eventually matched with the rest of the individual patient-level data that was available in the EHR. Disability was defined by USCB as serious difficulty with four basic areas of functioning - hearing, vision, cognition, and ambulation. Homemaker is any person that manages a home. Univariate and multivariate analysis were used to determine any hospitalization correlates. $\mathrm{P}$ values of less than 0.05 were considered statistically significant.

\section{Results}

\section{Participants}

As shown below in Table 1, a total of 11,304 hospitalized patients were studied, of which 1295 patients died, representing an in-hospital mortality rate of $11.5 \%$. The mean patient age of hospitalized patients was 63.77 years old and there was a nearly even split between males $(49.96 \%)$ and females $(50.04 \%)$. The median income of ZIP code was $\$ 56,521$. Half of all patients were married (45.99\%) and a quarter were single $(26.25 \%)$. The remaining were either widowed $(15.45 \%)$, divorced $(9.85 \%)$ or separated $(1.10 \%)$.

\section{Outcome Data}

For prediction of in-hospital mortality in the multivariate model, older age $(\mathrm{AOR}=1.05, \mathrm{p}<0.0001)$, male gender $(\mathrm{AOR}=1.43, \mathrm{p}<0.0001)$, divorced patients $(\mathrm{AOR}=1.25$, $\mathrm{p}=0.0256)$, disabled patients $(\mathrm{AOR}=1.42, \mathrm{p}=0.0091)$, and homemakers (AOR $=1.96, p=0.0216)$ were significantly associated with in-hospital mortality (Table 2). For each additional year of age, the odds of death increase by $5 \%(\mathrm{p}<0.0001)$. For each additional $\$ 1000$ increase in median Income of zip code, the odds of death decrease by $1 \%(\mathrm{p}=0.0059)$.

\section{Discussion}

We found that in-hospital mortality in COVID-19 patients was significantly associated with older age, male gender, divorced, disabled, and homemaker status. These findings are consistent with the current literature suggesting that elderly individuals and males tend to have higher risk of severe infection, hospitalizations and mortality related to COVID-19. ${ }^{1,4-6}$ As reported in our study, higher mortality rates have also been demonstrated amongst disabled patients. Currently, our study is the first to report associations between mortality and marital status, as well as homemaker status, in patients with COVID-19.

Interestingly, our study found no significant association between race alone and in-hospital mortality in COVID-19 patients, which differs from previous report findings. ${ }^{7}$ Many factors have been hypothesized to explain the racial disparity seen in COVID-19, including increased housing density, burden of chronic disease, poverty rate, likelihood of employment as essential workers as well as limited access to healthcare. ${ }^{8}$ This lack of disparity in our study potentially highlights the true underlying driver of increased mortality, disproportionate rates of comorbidities and socioeconomic disadvantages in minority groups, rather than race itself.

This study is novel, as we are the first to report mortality disparities associated with marital and homemaker status. Our findings may lead to further research and guide future preventative care and management of COVID-19 in these populations. With the rapid distribution of COVID19 vaccines in the United States, increased efforts should be taken to ensure vaccination of high-risk populations. Studies describing health disparities may be used to encourage vaccine administration through targeted campaigns, incentive programs, and vaccination clinics. Our research has implications for the long-term outcomes for individuals in the high-risk populations described in the study.

Limitations of this study include the retrospective nature as well as potential inaccuracies and missing data in the medical record. Further research should aim to understand the underlying factors driving these disparities in COVID-19 in-hospital mortality.

\section{Conclusion}

In conclusion, we report disparities associated with COVID19 mortality including older age, male gender, divorced patients, disabled patients, and homemakers. Further research should aim to identify the underlying factors driving these disparities in COVID-19 in-hospital mortality. 
Table I Participant Characteristics, Stratified by Death

\begin{tabular}{|c|c|c|c|c|}
\hline & $\begin{array}{l}\text { All Patients } \\
(\mathrm{N}=1 \mathrm{I}, \mathbf{3 0 4})\end{array}$ & $\begin{array}{l}\text { Deceased } \\
(N=1295)\end{array}$ & $\begin{array}{l}\text { Alive } \\
(\mathrm{N}=10,009)\end{array}$ & p-value \\
\hline $\begin{array}{l}\text { Age of Patient (Years) } \\
\text { Mean (Standard Deviation) }\end{array}$ & 63.77 (17.79) & 73.15 (12.89) & $62.52(17.94)$ & $<0.0001$ \\
\hline $\begin{array}{l}\text { Unemployment Rate of ZIP Code (\%) } \\
\text { Mean (Standard Deviation) }\end{array}$ & $7.44 \%$ (4.78\%) & $7.29 \%$ (4.64\%) & $7.46 \%$ (4.80\%) & 0.2325 \\
\hline $\begin{array}{l}\text { Percent of ZIP Code Working in White Collar Profession (\%) } \\
\text { Mean (Standard Deviation) }\end{array}$ & $35.69 \%$ (I3.87\%) & $36.51 \%$ (13.74\%) & $35.57 \%$ (I3.88\%) & 0.0321 \\
\hline $\begin{array}{l}\text { Percent of ZIP Code Working in Service Profession (\%) } \\
\text { Mean (Standard Deviation) }\end{array}$ & I8.4I\% (5.59\%) & $18.09 \%(5.46 \%)$ & $18.45 \%(5.60 \%)$ & 0.0278 \\
\hline $\begin{array}{l}\text { Median Income of ZIP Code }(\$) \\
\text { Mean (Standard Deviation) }\end{array}$ & $\begin{array}{l}\$ 60,704.80 \\
(\$ 25,539.92)\end{array}$ & $\begin{array}{l}\$ 60,982.56 \\
(\$ 25,155.67)\end{array}$ & $\begin{array}{l}\$ 60,663.85 \\
(\$ 25,595.32)\end{array}$ & 0.6734 \\
\hline $\begin{array}{l}\text { Poverty Rate of ZIP Code (\%) } \\
\text { Mean (Standard Deviation) }\end{array}$ & $13.41 \%(\mid 0.82 \%)$ & $13.30 \%(10.75 \%)$ & $13.43 \%(10.83 \%)$ & 0.6889 \\
\hline $\begin{array}{l}\text { Biological Sex of Patient } \\
\text { Female } \\
\text { Male }\end{array}$ & $\begin{array}{l}5657 \text { (50.04\%) } \\
5647 \text { (49.96\%) }\end{array}$ & $\begin{array}{l}553(42.70 \%) \\
742(57.30 \%)\end{array}$ & $\begin{array}{l}5095 \text { (50.96\%) } \\
4903 \text { (49.04\%) }\end{array}$ & $<0.0001$ \\
\hline $\begin{array}{l}\text { Race of Patient } \\
\text { American Indian or Alaska Native } \\
\text { Asian } \\
\text { Black or African American } \\
\text { Native Hawaiian or Pacific Islander } \\
\text { Other } \\
\text { White or Caucasian } \\
\text { Unknown }\end{array}$ & $\begin{array}{l}34(0.30 \%) \\
230(2.03 \%) \\
3684(32.59 \%) \\
5(0.04 \%) \\
699(6.18 \%) \\
6646(58.79 \%) \\
6(0.05 \%)\end{array}$ & $\begin{array}{l}3(0.23 \%) \\
26(2.01 \%) \\
392(30.27 \%) \\
0(0.00 \%) \\
73(5.64 \%) \\
800(61.78 \%) \\
1(0.08 \%)\end{array}$ & $\begin{array}{l}31(0.31 \%) \\
204(2.04 \%) \\
3288(32.89 \%) \\
5(0.05 \%) \\
624(6.24 \%) \\
5841(58.42 \%) \\
5(0.05 \%)\end{array}$ & 0.3875 \\
\hline $\begin{array}{l}\text { Ethnicity of Patient } \\
\text { Arabic or Middle Eastern } \\
\text { Hispanic or Latino } \\
\text { Not Hispanic or Latino } \\
\text { Other } \\
\text { Unknown }\end{array}$ & $\begin{array}{l}1139(10.08 \%) \\
351(3.11 \%) \\
9273(82.03 \%) \\
440(3.89 \%) \\
101(0.89 \%)\end{array}$ & $\begin{array}{l}123(9.50 \%) \\
30(2.32 \%) \\
1085(83.78 \%) \\
44(3.40 \%) \\
13(1.00 \%)\end{array}$ & $\begin{array}{l}1016(10.16 \%) \\
321(3.21 \%) \\
8180(81.82 \%) \\
393(3.93 \%) \\
88(0.88 \%)\end{array}$ & 0.2844 \\
\hline $\begin{array}{l}\text { Marital Status } \\
\text { Divorced } \\
\text { Married } \\
\text { Separated } \\
\text { Single } \\
\text { Widowed } \\
\text { Unknown }\end{array}$ & $\begin{array}{l}1114(9.85 \%) \\
5199(45.99 \%) \\
124(1.10 \%) \\
2967(26.25 \%) \\
1746(15.45 \%) \\
154(1.36 \%)\end{array}$ & $\begin{array}{l}154(11.89 \%) \\
589(45.48 \%) \\
10(0.77 \%) \\
260(20.08 \%) \\
259(20.00 \%) \\
23(1.78 \%)\end{array}$ & $\begin{array}{l}958(9.58 \%) \\
4609(46.10 \%) \\
114(1.14 \%) \\
2707(27.08 \%) \\
1480(14.80 \%) \\
130(1.30 \%)\end{array}$ & $<0.0001$ \\
\hline $\begin{array}{l}\text { Primary Payor } \\
\text { Private Insurance } \\
\text { Uninsured } \\
\text { Medicaid } \\
\text { Medicare } \\
\text { Tricare/VA }\end{array}$ & $\begin{array}{l}6005(53.12 \%) \\
132(1.17 \%) \\
382(3.38 \%) \\
4760(42.11 \%) \\
25(0.22 \%)\end{array}$ & $\begin{array}{l}483(37.30 \%) \\
8(0.62 \%) \\
24(1.85 \%) \\
777(60.00 \%) \\
3(0.23 \%)\end{array}$ & $\begin{array}{l}5520(55.21 \%) \\
124(1.24 \%) \\
358(3.58 \%) \\
3974(39.75 \%) \\
22(0.22 \%)\end{array}$ & $<0.0001$ \\
\hline
\end{tabular}


Table 2 Multivariate Model to Predict Death

\begin{tabular}{|c|c|c|}
\hline & AOR (95\% Cl) & p-value \\
\hline Age of Patient (Years) & $1.05(1.04,1.05)$ & $<0.0001$ \\
\hline $\begin{array}{l}\text { Median Income of ZIP } \\
\text { Code ( } \$ 1000 \text { USD) }\end{array}$ & $0.99(0.99,0.99)$ & 0.0059 \\
\hline $\begin{array}{l}\text { Biological Sex of Patient } \\
\text { Male } \\
\text { Female }\end{array}$ & $\begin{array}{l}1.43(1.26,1.63) \\
\text { Reference Group }\end{array}$ & $<0.0001$ \\
\hline $\begin{array}{l}\text { Marital Status } \\
\text { Divorced } \\
\text { Separated } \\
\text { Single } \\
\text { Unknown } \\
\text { Widowed } \\
\text { Married }\end{array}$ & $\begin{array}{l}\mathrm{I} .25(\mathrm{I} .03, \mathrm{I} .53) \\
0.80(0.42, \mathrm{I} .53) \\
\mathrm{I} .06(0.90, \mathrm{I} .25) \\
\mathrm{I} .24(0.76,2.0 \mathrm{I}) \\
0.78(0.66,0.94) \\
\text { Reference Group }\end{array}$ & $\begin{array}{l}0.0256 \\
0.4992 \\
0.5139 \\
0.3898 \\
0.0074\end{array}$ \\
\hline $\begin{array}{l}\text { Employment Status } \\
\text { Disabled } \\
\text { Homemaker } \\
\text { Not Employed } \\
\text { Part Time } \\
\text { Retired } \\
\text { Self Employed } \\
\text { Student } \\
\text { Unknown } \\
\text { Full Time }\end{array}$ & $\begin{array}{l}1.42(1.09,1.85) \\
1.96(1.10,3.47) \\
1.19(0.95, I .50) \\
0.65(0.36, I .17) \\
1.19(0.95, I .49) \\
0.89(0.49,1.59) \\
1.94(0.11,35.5) \\
1.89(1.31,2.7 \mathrm{I}) \\
\text { Reference Group }\end{array}$ & $\begin{array}{l}0.0091 \\
0.0216 \\
0.1291 \\
0.1517 \\
0.1204 \\
0.6847 \\
0.6555 \\
0.0006\end{array}$ \\
\hline
\end{tabular}

\section{Data Sharing Statement}

The data used to support the findings of this study are available from the corresponding author upon request.

\section{Ethics Approval}

The study was approved by the Beaumont Health Institutional Review Board. The study was approved under expedited review and the patient consent was waived as the study design was retrospective. The data confidentiality and compliance with the Declaration of Helsinki were maintained.

\section{Funding}

This research did not receive any specific funding.

\section{Disclosure}

The authors have no conflicts of interest regarding the publication of this paper.

\section{References}

1. Carethers JM. Insights into disparities observed with COVID-19. J Intern Med. 2021;289(4):463-473. PMID: 33164230. doi:10.1111/ joim. 13199

2. Halalau A, Imam Z, Karabon P, et al. External validation of a clinical risk score to predict hospital admission and in-hospital mortality in COVID-19 patients. Ann Med. 2021;53(1):78-86. PMID: 32997542; PMCID: PMC7877986. doi:10.1080/07853890.2020.1828616

3. Kim EJ, Marrast L, Conigliaro J. COVID-19: magnifying the effect of health disparities. J Gen Intern Med. 2020;35:2441. doi:10.1007/ s11606-020-05881-4

4. Halalau A, Odish F, Imam Z, et al. Epidemiology, clinical characteristics, and outcomes of a large Cohort of COVID-19 outpatients in Michigan. Int J Gen Med. 2021;14:1555-1563. doi:10.2147/IJGM. S305295

5. Imam Z, Odish F, Armstrong J, et al. Independent correlates of hospitalization in 2040 patients with COVID-19 at a large hospital system in Michigan, United States. J Gen Intern Med. 2020;35 (8):2516-2517. doi:10.1007/s11606-020-05937-5

6. Kopel J, Perisetti A, Roghani A, Aziz M, Gajendran M, Goyal H. Racial and gender-based differences in COVID-19. Front Public Health. 2020;8:418. doi:10.3389/fpubh.2020.00418

7. Yancy CW. COVID-19 and African Americans. JAMA. 2020;323 (19):1891-1892. doi:10.1001/jama.2020.6548

8. Louis-Jean J, Cenat K, Njoku CV, Angelo J, Sanon D. Coronavirus (COVID-19) and racial disparities: a perspective analysis. $J$ Racial Ethn Health Disparities. 2020;7(6):1039-1045. doi:10.1007/s40615020-00879-4

\section{Dovepress}

\section{Publish your work in this journal}

The International Journal of General Medicine is an international, peer-reviewed open-access journal that focuses on general and internal medicine, pathogenesis, epidemiology, diagnosis, monitoring and treatment protocols. The journal is characterized by the rapid reporting of reviews, original research and clinical studies

across all disease areas. The manuscript management system is completely online and includes a very quick and fair peer-review system, which is all easy to use. Visit http://www.dovepress.com/ testimonials.php to read real quotes from published authors. 